\title{
Anti-aging skin and antioxidant assays of protein hydrolysates obtained from salted shrimp fermented with Salinivibrio cibaria BAO-01
}

\author{
Pham Thi Ngoc Anh ${ }^{1} \cdot$ Bao $^{2} \cdot$ Seung Hwan Yang ${ }^{1}$ (D) \\ Received: 25 June 2020 / Accepted: 12 August 2020 / Published Online: 30 September 2020 \\ (C) The Korean Society for Applied Biological Chemistry 2020
}

\begin{abstract}
This study focused on the preparation and characterization of anti-wrinkle peptides from the salted and fermented shrimp (Acetes japonicus) inoculated with Salinivibrio cibaria BAO-01 (SFSC). The results showed the proximate composition of SFSC to be $9.23 \%$ water, $75.32 \%$ protein, $0.23 \%$ fat, and $13.3 \mathrm{mg} / \mathrm{g}$ ash. Interestingly, the $S$. cibaria fermentation significantly increased the amount of methionine, leucine, and arginine. The in vitro antioxidant activity was assayed by the diphenylpicrylhydrazyl method and its $\mathrm{IC}_{50}$ value was found to be $43.02 \pm 2.84 \mu \mathrm{g} / \mathrm{mL}$. It was observed to inhibit the activity of elastase, tyrosinase, collagenase, and hyaluronidase. The $\mathrm{IC}_{50}$ values of SFSC were $182.75 \pm 12.38 \mu \mathrm{g} / \mathrm{mL}$ for anti-elastase activity, $186.78 \pm 7.95 \mu \mathrm{g} / \mathrm{mL}$ for anti-tyrosinase activity, $444.4 \pm 34.81 \mu \mathrm{g} / \mathrm{mL}$ for anti-collagenase activity, and $1447.95 \pm 28.92 \mu \mathrm{g} / \mathrm{mL}$ for anti-hyaluronidase activity. These results suggest that salted and fermented shrimp has strong potential for the development of nutricosmetic products.
\end{abstract}

Keywords Anti-aging $\cdot$ Antioxidant $\cdot$ Protein $\cdot$ Salted shrimp

\section{Introduction}

The presence of wrinkles is an indication of the aging of skin, an inevitable process instigated by several factors, both intrinsic and

Seung Hwan Yang $(\bowtie)$

E-mail: ymichigan@jnu.ac.kr

${ }^{1}$ Department of Biotechnology, Chonnam National University, Yeosu 59626, Republic of Korea

${ }^{2}$ Faculty of Pharmacy, Ton Duc Thang University, Ho Chi Minh City, 700000 , Vietnam

This is an Open Access article distributed under the terms of the Creative Commons Attribution Non-Commercial License (http://creativecommons. org/licenses/by-nc/3.0/) which permits unrestricted non-commercial use, distribution, and reproduction in any medium, provided the original work is properly cited. extrinsic [1]. Intrinsic aging of skin, also called age-dependent aging or chronologic aging, is caused by internal physiological factors, while extrinsic aging is caused by many external factors, including exposure of the skin to UV radiation, cigarette smoking, and air pollution. These factors generate exogenous reactive oxygen species, which overwhelm antioxidant defense mechanisms, leading to degradation of elastin and collagen, deposition of glycosaminoglycans, and induction of melanin biosynthesis [2]. Exposure to UV increases the production of collagenase, elastase, and hyaluronidase, which degrade the abundant collagen and elastin of the extracellular matrix (ECM) [3]. Collagenase, a zincdependent endopeptidase, is capable of degrading type 1 collagen. Elastase, a protease enzyme, breaks down elastin and collagen which determine the mechanical and structural properties of the connective tissue in the ECM. Hyaluronidase is a mucopolysaccharide-degrading enzyme that hydrolyses the $\beta$-1,4-glycosidic bonds of hyaluronic acid and induces a decrease in its viscosity. Inhibitors of these enzymes can be used for the process of renewal and recovery of aging skin.

Anti-aging strategies for the skin are complex, and can involve multiple, concurrent treatments. These include cosmetic care, topical bioactive agents, invasive procedures, systemic agents, preventative medicine, the avoidance of exogenous factors and correction of lifestyle and habits [4]. Nutrition is a promising strategy for cellular maintenance and renewal, and for erasing the effects of skin aging, that is also healthy and safe. Peptide molecules, especially small fragments (2-20 amino acids), have been investigated as a safe, emerging therapy for the care of skin, nails, and hair [5,6]. Recently, the skin-care industry has begun to manufacture peptide-based products, including creams, lotions, and nutritional supplements [6]. There is a current need for studies to evaluate potential peptide sources for nutricosmetics, and to establish their effects on human health and on metabolic parameters.

Fermented fish products are a rich source of bioactive peptides. During the fermentation process, cleavage of food proteins by microbial or indigenous proteases yields bioactive peptides, leading to a substantial increase in the biological activity of the 
food [7]. Over the last decade, many peptides have been identified in fermented fish foods and have been shown to exhibit activities such as antihypertensive, antimicrobial, obesity control, immunomodulatory, anticancer, antithrombotic, opioid, and antioxidant $[8$, 10]. Some cosmeceutical products containing fish protein and peptides can enhance collagen synthesis, chemotaxis, and protect skin from the effects of UV radiation [11]. The anti-photoaging effect of a low-molecular-weight collagen peptide purified from catfish skin (Pangasius hypophthalmus) was evaluated in animal models and in a clinical trial [12].

Salted and fermented shrimp products are popular in SouthEast Asian countries, such as Korea, Thailand, China, and Japan [13]. In Korea, salted and fermented shrimps are produced by mixing whole shrimp, Acetes japonicus with 5-20\% salt and storing for several months at ambient temperature. The fish fermentation process consists of the transformation of organic substances into simpler compounds, such as amino acids, peptides, and various nitrogenous compounds. There are some studies on the antioxidant activity of shrimp peptides; however, to the best of our knowledge, no report exists of their anti-wrinkle properties. Salinivibrio is the predominant bacterial genus in fermented seafoods [14]. These bacteria produce numerous enzymes such as lipase, cellulase, and chitinase with antifungal and antimicrobial properties [15]. Therefore, the aim of this study was to determine the anti-elastase, anti-collagenase, and anti-hyaluronidase activities of salted and fermented shrimp protein extracts, obtained from salted shrimp fermented with Salinivibrio cibaria.

\section{Materials and Methods}

\section{Salted and fermented shrimp preparation}

The use of Salinivibrio cibaria BAO-01 as a starter culture was previous characterized [16]. A $1 \%(\mathrm{v} / \mathrm{v})$ inoculum is placed in marine broth (Difco, Detroit, MI, USA), supplemented with 5\% sodium chloride, and incubated at $37^{\circ} \mathrm{C}$ for $24 \mathrm{~h}$ in static conditions. To prepare salted and fermented shrimp inoculated with Salinivibrio cibaria BAO-01 (SFSC), fresh shrimp (Acetes japonicus) was provided by Shinan Saujeot Inc., mixed well with solar salt (sun-evaporated) at a ratio of $20 \%$ salt to $80 \%$ shrimp, and stacked in glass containers. A $1 \%$ starter culture $\left(10^{8}\right.$ cells/ $\mathrm{mL}$ ) was used and the containers were capped and allowed to stand at room temperature $\left(25^{\circ} \mathrm{C}\right)$ for $3 \mathrm{~min}$. The containers contain shrimps and salts without starter culture as used as control (SFS). After the fermentation process was complete, SFS and SFSC samples were minced with a heavy-duty meat mincer (MGT0012, Nemco Food Equipment Ltd., Hicksville, OH, USA), freeze-dried and stored at $-20{ }^{\circ} \mathrm{C}$.

\section{Preparation of water extract}

The salted and fermented shrimp protein extract was prepared using an enzymatic process. Fifty grams of thawed sample mince was suspended $(1: 1, \mathrm{w} / \mathrm{v})$ in distilled water in Sorvall ${ }^{\mathrm{TM}}$ bottles and the mixture was brought to $90{ }^{\circ} \mathrm{C}$ for $30 \mathrm{~min}$ to inactivate the endogenous enzymes. The mixture was then homogenized, and $\mathrm{pH}$ was adjusted to 8.5 with $1 \mathrm{~N} \mathrm{NaOH}$. The enzyme alcalase ${ }^{\circledR}$, a bacterial endoproteinase from Bacillus licheniformis, with a declared activity of $2.4 \mathrm{AU} / \mathrm{g}$ and a density of $1.18 \mathrm{~g} / \mathrm{mL}$, was procured from Sigma Aldrich (St. Louis, MO, USA) and added at an enzyme to substrate ratio of $1.5 \mathrm{~g} / 100 \mathrm{~g}$ substrate. The enzymatic process was carried out at $60{ }^{\circ} \mathrm{C}$ for $20 \mathrm{~min}$ in a shaking water bath. After the completion of hydrolysis, alcalase was deactivated by holding the sample at $90{ }^{\circ} \mathrm{C}$ for $5 \mathrm{~min}$. After cooling to room temperature, the hydrolyzed mixture was filtered with sterile gauze, and centrifuged (AvantiTM J-25 I, Beckman Coulter, California, USA) at $7500 \times \mathrm{g}$ for $15 \mathrm{~min}$ at $4{ }^{\circ} \mathrm{C}$. The supernatant was concentrated in a rotary evaporator, lyophilized using a freeze drier (Freeze dryer, Ilshin FD5505, Siheung, Korea), and stored in polypropylene tubes $(50 \mathrm{~mL})$ at $-20{ }^{\circ} \mathrm{C}$ until use.

\section{Proximate analysis}

The extracts was analyzed for moisture, ash, protein, and fat content, according to AOAC official methods [17]. In brief, the samples $(1 \mathrm{~g})$ were dried at $105^{\circ} \mathrm{C}$ in an oven, to a constant weight. The moisture content was calculated by weight difference before and after the drying process. After that, ash content was determined by incineration of a dried sample mass at $600{ }^{\circ} \mathrm{C}$. The protein content was measured by the Kjeldahl method and quantified by multiplying total percentage nitrogen by a factor of 6.38. The fat content was extracted by chloroform-methanol followed by the Mojonnier method.

\section{Free amino acid composition}

To determine the free amino acid composition, samples will firstly mixed with $6 \%(\mathrm{v} / \mathrm{v})$ perchloric acid and then followed the extraction protocol of Thuy, Okazaki et al. [18]. The lysates were subsequently neutralized and filtered. The filtrate was used for amino acid analysis using the Prominence HPLC System (Shimadzu, Kyoto, Japan) equipped with a column (Shim-pack Amino-Li, $100 \mathrm{~mm} \times 6.0 \mathrm{~mm}$ i.d.; column temperature, $39^{\circ} \mathrm{C}$; Shimadzu) and pre-column (Shimpack ISC-30/S0504 Li, $150 \mathrm{~mm} \times 4.0 \mathrm{~mm}$ i.d.; Shimadzu). Amino acids were detected using a fluorescence detector (RF-10AXL; Shimadzu). The content was reported as $\mathrm{mg} / \mathrm{g}$ dry weight of sample.

\section{Antioxidant scavenging activity assay}

The diphenylpicrylhydrazyl (DPPH) radical-scavenging activity was determined as described by Yen and $\mathrm{Wu}$ [19] using butylated hydroxyanisole (BHA) as the standard compound. The percentage radical scavenging activity was calculated based on the following equation:

$$
\text { DPPH Scavenged }(\%)=\left(\mathrm{A}_{\text {cont }}-\mathrm{A}_{\text {sample }}\right) / \mathrm{A}_{\text {cont }} \times 100
$$

$\mathrm{A}_{\text {cont }}$ and $\mathrm{A}_{\text {sample }}$ are the absorbance values for the control and sample, respectively. 


\section{Elastase inhibitory assay}

The elastase inhibitory activity of salted shrimp samples were evaluated in vitro using a porcine pancreatic elastase (PPE) enzyme inhibitory assay [20]. Briefly, porcine pancreatic elastase was dissolved in sterile water to make a 100 unit stock solution. The substrate N-Succinyl-Ala-Ala-Ala-p-nitroanilide (AAAPVN) was dissolved in $0.2 \mathrm{M}$ Tris-HCL buffer $(\mathrm{pH} 8.0)$ buffer. The extracts were incubated with the enzyme for $25 \mathrm{~min}$ before adding substrate to start the reaction. The final reaction mixture $(250 \mu \mathrm{L})$ contained buffer, $10 \mu \mathrm{g} / \mathrm{mL}$ AAAPVN, 0.001 units PPE and 500 $\mu \mathrm{g} / \mathrm{mL}$ of shrimp extract. After incubation for $10 \mathrm{~min}$, the absorbance was measured at $410 \mathrm{~nm}$ and inhibition values for each sample were calculated as follows:

Inhibition $(\%)=[1-($ Sample - Blank $) /($ Control - Blank $)] \times 100$

where Blank is before incubation, Control is without sample, after incubation. Ursolic acid was used as positive control.

\section{Tyrosinase inhibitory assay}

The activity of mushroom tyrosinase was determined spectrophotometrically, as described by Schurink, van Berkel et al. [21]. The reaction mixture $(1000 \mu \mathrm{L})$ contained $685 \mu \mathrm{L}$ of $0.1 \mathrm{M}$ phosphate buffer $\mathrm{pH} 6.5,15 \mu \mathrm{L}$ of $2500 \mathrm{U} / \mathrm{mL}$ mushroom tyrosinase in phosphate buffer, $200 \mu \mathrm{L}$ of various concentrations of SFSC extract and $100 \mu \mathrm{L}$ of $5 \mathrm{mM} \mathrm{L-3,4-dihydroxyphenylalanine} \mathrm{(DOPA).}$ Once the DOPA was added, the reaction was monitored at $492 \mathrm{~nm}$ for dopachrome formation in the mixture. Ursolic acid was used as a positive control. After incubating the mixture at $37^{\circ} \mathrm{C}$ for 30 min, the optical density was measured at $490 \mathrm{~nm}$, using a microplate reader.

\section{Collagenase inhibitory assay}

The collagenase inhibitory assay was performed with an MMP1 Human ELISA kit (Amersham, Little Chalfont, UK), according to the manufacturer's protocol. The 4phenylazobezyloxylcarbonyl ProLeuGlyProArg (the synthetic substrate) was dissolved in reaction buffer at $0.3 \mathrm{mg} / \mathrm{mL}$, and $250 \mu \mathrm{L}$ was added in the reaction tube with $100 \mu \mathrm{L}$ of various concentrations of SFSC extract $(1000,500,250,125$, and $62.5 \mu \mathrm{g} / \mathrm{mL})$ or epigallocatechin gallate (EGCG) $(20 \mu \mathrm{M})$. Collagenase was dissolved in the buffer at $0.2 \mathrm{mg} / \mathrm{mL}$ and $150 \mu \mathrm{L}$ of this was added to the reaction tube. After incubation at $25^{\circ} \mathrm{C}$ for $20 \mathrm{~min}$, the reaction was stopped by addition of $6 \%$ citric acid. The reaction mixture was separated using $1.5 \mathrm{~mL}$ of ethyl acetate. The absorbance was measured at $320 \mathrm{~nm}$ using a microplate reader.

\section{Hyaluronidase inhibitory assay}

Hyaluronidase inhibition was determined by measuring the amount of $\beta$-N-acetylglucosamine formed from sodium hyaluronate. A stock of enzyme was prepared by dissolve bovine hyaluronidase (7420 units) in $1 \mathrm{~mL}$ of $0.1 \mathrm{M}$ acetate buffer; $\mathrm{pH}$ 5.6. The $500 \mu \mathrm{L}$ of enzyme stock was activated by mixing with $100 \mu \mathrm{L}$ calcium chloride $(0.25 \mathrm{mM})$ and then incubated in a water bath at $37{ }^{\circ} \mathrm{C}$ for $20 \mathrm{~min}$. The reaction was started by the addition of $500 \mu \mathrm{L}$ of sample serial dilutions. After $20 \mathrm{~min}, 500 \mu \mathrm{L}$ of sodium hyaluronate was added $(0.5 \mathrm{mg} / \mathrm{mL}$ in $0.1 \mathrm{M}$ acetate buffer; $\mathrm{pH}$ 5.6). After a 30 -min incubation, the reaction was stopped by adding $100 \mu \mathrm{L}$ of $0.4 \mathrm{M}$ sodium hydroxide. Next, $500 \mu \mathrm{L}$ acetylacetone was added, and the mixture was placed in boiling water for $30 \mathrm{~min}$ to produce a chromogenic reaction. After cooling to $25^{\circ} \mathrm{C}, 1.0 \mathrm{~mL}$ of pdimethylaminobenzaldehyde solution was added to the reaction mixture for $20 \mathrm{~min}$ at $25^{\circ} \mathrm{C}$. The optical density of the reaction mixture was measured at $555 \mathrm{~nm}$ using a microplate reader (Infinite 200; TECAN Group Ltd., Männedorf, Switzerland) Three independent assays were performed in triplicate.

\section{Sensory evaluation}

A sensory analysis was performed with a group of 20 untrained panelists to evaluate differences between the SFS and SFSC samples, using a 9-point hedonic scale. The panelists were asked to rate samples for softness, fibrousness, sweetness, bitterness, sourness, aroma intensity, aftertaste, and overall preference with 1 representing "dislike extremely" and 9 representing "like extremely" for each sample. Sensory evaluation was conducted in individual booths to prevent rate score bias.

\section{Statistical analysis}

All experiments were conducted in triplicate. Statistical analysis was done by using one-way analysis of variance (ANOVA) to determinate significant differences within and between groups, followed by Duncan's multiple range test. These analyses were performed using the SPSS package (Version 22.0) (SPSS Inc., Chicago, IL, USA). Outcomes of sensory evaluation were analyzed using the paired-sample t-test.

\section{Results and Discussion}

Previous studies have revealed that peptides obtained from shrimps have a range of bioactivity, such as antihypertensive, antioxidant, antimicrobial, neuroprotection, antihyperglycemic, and anti-aging $[9,22,23]$. Therefore, we hypothesized that fermented shrimp might be able to enhance health without having side effects.

\section{Proximate composition}

The proximate composition of SFSC extract comprised 9.23\% water, $75.32 \%$ protein, $0.23 \%$ fat, and $13.3 \mathrm{mg} / \mathrm{g}$ ash (Table 1). Its high protein content was due to solubilization of protein during enzymatic hydrolysis and the exclusion of insoluble, indigestible, non-protein isolates. This was comparable with the composition of shrimp protein extract, reported in previous studies [24,25]. The moisture content is linked to the type of sample and to the temperatures employed during the drying process. The ash content is in the previously reported range of $8.25-23.4 \%$ [25,26]. Variation 
Table 1 Proximate composition of salted fermented shrimps

\begin{tabular}{cccc}
\hline \hline Composition (\%) & Moisture & Protein & Fat \\
\hline SFS & $9.23 \pm 1.4$ & $75.32 \pm 0.82$ & $0.23 \pm 0.08$ \\
SFSC & $9.87 \pm 0.6$ & $73.95 \pm 0.49$ & $0.34 \pm 0.07$ \\
\hline
\end{tabular}

Values was expressed as g per $100 \mathrm{~g}$ dry weight. Mean \pm SD from triplicate determinations

Table 2 Amino acid composition of salted and fermented shrimps (mg/g protein)*

\begin{tabular}{lcc}
\hline \multicolumn{1}{c}{ Free amino acid } & SFS & SFSC \\
\hline Thr & $4.23 \pm 0.31$ & $4.12 \pm 0.16$ \\
Asp & $2.83 \pm 0.16^{\mathrm{b}}$ & $3.75 \pm 0.21^{\mathrm{a}}$ \\
Ser & $3.96 \pm 0.15$ & $3.59 \pm 0.15$ \\
Glu & $15.23 \pm 0.21$ & $14.93 \pm 0.16$ \\
Pro & $2.13 \pm 0.07$ & $2.32 \pm 0.13$ \\
Gly & $2.45 \pm 0.12$ & $2.41 \pm 0.01$ \\
Ala & $8.01 \pm 0.09$ & $8.03 \pm 0.09$ \\
Val & $6.89 \pm 0.11$ & $5.68 \pm 0.14$ \\
Cys & $2.18 \pm 0.03$ & $2.35 \pm 0.03$ \\
Met & $4.82 \pm 0.12^{\mathrm{a}}$ & $1.96 \pm 0.11^{\mathrm{b}}$ \\
Ile & $4.23 \pm 0.04$ & $4.23 \pm 0.04$ \\
Leu & $12.42 \pm 0.03^{\mathrm{a}}$ & $9.11 \pm 0.06^{\mathrm{b}}$ \\
Tyr & $4.06 \pm 0.11$ & $4.35 \pm 0.05$ \\
Phe & $4.11 \pm 0.12^{\mathrm{b}}$ & $5.24 \pm 0.03^{\mathrm{a}}$ \\
Lys & $7.89 \pm 0.21^{\mathrm{b}}$ & $11.84 \pm 0.16^{\mathrm{a}}$ \\
His & $3.89 \pm 0.10$ & $3.59 \pm 0.04$ \\
Trp & $1.23 \pm 0.08^{\mathrm{b}}$ & $4.24 \pm 0.04^{\mathrm{a}}$ \\
Arg & $9.36 \pm 0.12^{\mathrm{a}}$ & $6.31 \pm 0.18^{\mathrm{b}}$ \\
Total essential amino acid $(\%)$ & $61.9 \pm 0.14^{\mathrm{a}}$ & $56.43 \pm 0.09^{\mathrm{b}}$ \\
Total hydrophobic amino acid $(\%)$ & $43.84 \pm 0.13^{\mathrm{a}}$ & $40.81 \pm 0.15^{\mathrm{b}}$ \\
Total hydrophilic amino acid $(\%)$ & $34.94 \pm 0.09$ & $35.5 \pm 0.07$ \\
\hline
\end{tabular}

*Values presented are means of triplicates $\pm \mathrm{SD}$

${ }^{\mathrm{a}, \mathrm{b}}$ The different letters in the same line represent that there are significant differences at the level of $p<0.05$

in ash content is due to the mineral content of the sample and the addition of an acid or base to adjust the $\mathrm{pH}$ during hydrolysis [27]. The protein content is higher than the $46.52-47.01 \%$ reported by Dhanabalan, Xavier et al. [24] for Acetes indicus and GhorbelBellaaj, Maalej et al. [25] from the fermented shrimp waste hydrolysate of Metapeneaus Monoceros. It is lower, however, than the $91.37 \%$ reported by Najafian and Babji [8] for fermented Loma fish (Thynnichthys thynnoides).

\section{Amino acid composition of protein extract}

In order to identify the contribution of S. cibaria BAO-01 to the amino acid profile, the comparison between the free amino acid composition of SFS (fermented shrimp paste without S. cibaria, the control) and SFSC protein extracts is presented in Table 2. The inoculum of $S$. cibaria significantly increased the total essential amino acid content of the protein extract. SFSC showed a higher

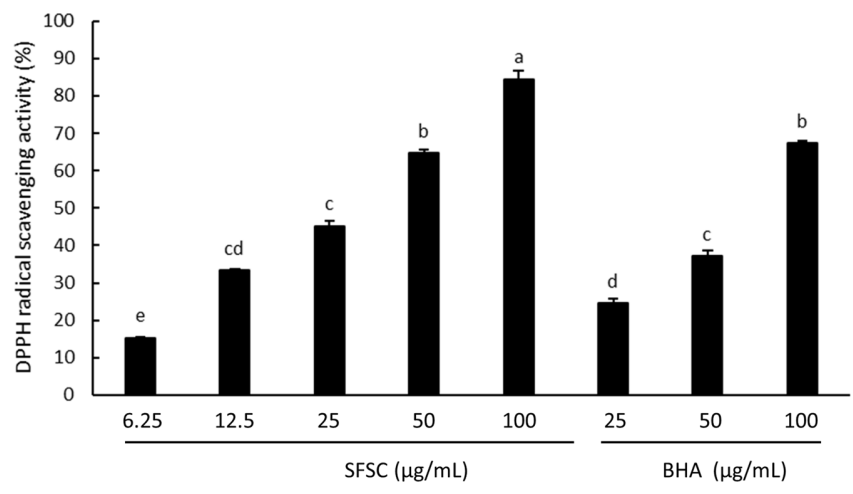

Fig. 1 DPPH scavenging activities of salted and fermented shrimps. All data are presented as the mean $\pm \mathrm{SD}$ of triplicate results. ${ }^{\text {a-e }}$ Values with different letters indicated significant differences in the same free radical at different concentrations $(p<0.05)$

proportion of lysine $(118.4 \mathrm{mg} / \mathrm{g}$ protein) and leucine $(91.1 \mathrm{mg} / \mathrm{g}$ protein), among essential amino acids, while glutamate (149.3 $\mathrm{mg} / \mathrm{g}$ protein) contributed the highest proportion of the total amino acid content. Glutamate, which has a savory flavor, was the most abundant amino acid in both SFS and SFSC, in agreement with the composition of other shrimp pastes [24]. The leucine concentration of SFSC was significantly higher than that produced in SFS. Le Vo, Pham et al. [28] produced fresh A. japonicus hydrolysate using Flavourzyme ${ }^{\circledR}$ and also found a high level of leucine (111.5 $\mathrm{mg} / \mathrm{g}$ protein) and the non-essential amino acid arginine (182.0 $\mathrm{mg} / \mathrm{g}$ protein). The content of hydrophobic amino acids was high, accounting for nearly $43.8 \%$ of total amino acids. The abundance of hydrophobic amino acids has been found to affect the antioxidant activity of protein hydrolysates. Moreover, the amino acid profile of the SFS protein extract was found to meet the recommended pattern of amino acid requirements for elderly people, as designated by FAO/WHO (2013).

\section{DPPH radical scavenging assay}

Antioxidants play a vital role in protecting skin from UV exposure and aging. Free radical scavengers prevent UV-induced skin damage through their inhibition of the expression and activity of matrix metalloproteinases (MMPs). They also stimulate the inflammatory process, reflect the degree of oxidative stress, and maintain a normal physiologic state [29]. Recently, several studies have been conducted to enhance bioactive peptides present in seafoods and its fermented products [30,31]. In the present study, we found that the DPPH radical scavenging activity of SFSC extract increased with protein concentration (Fig. 1). The radical 

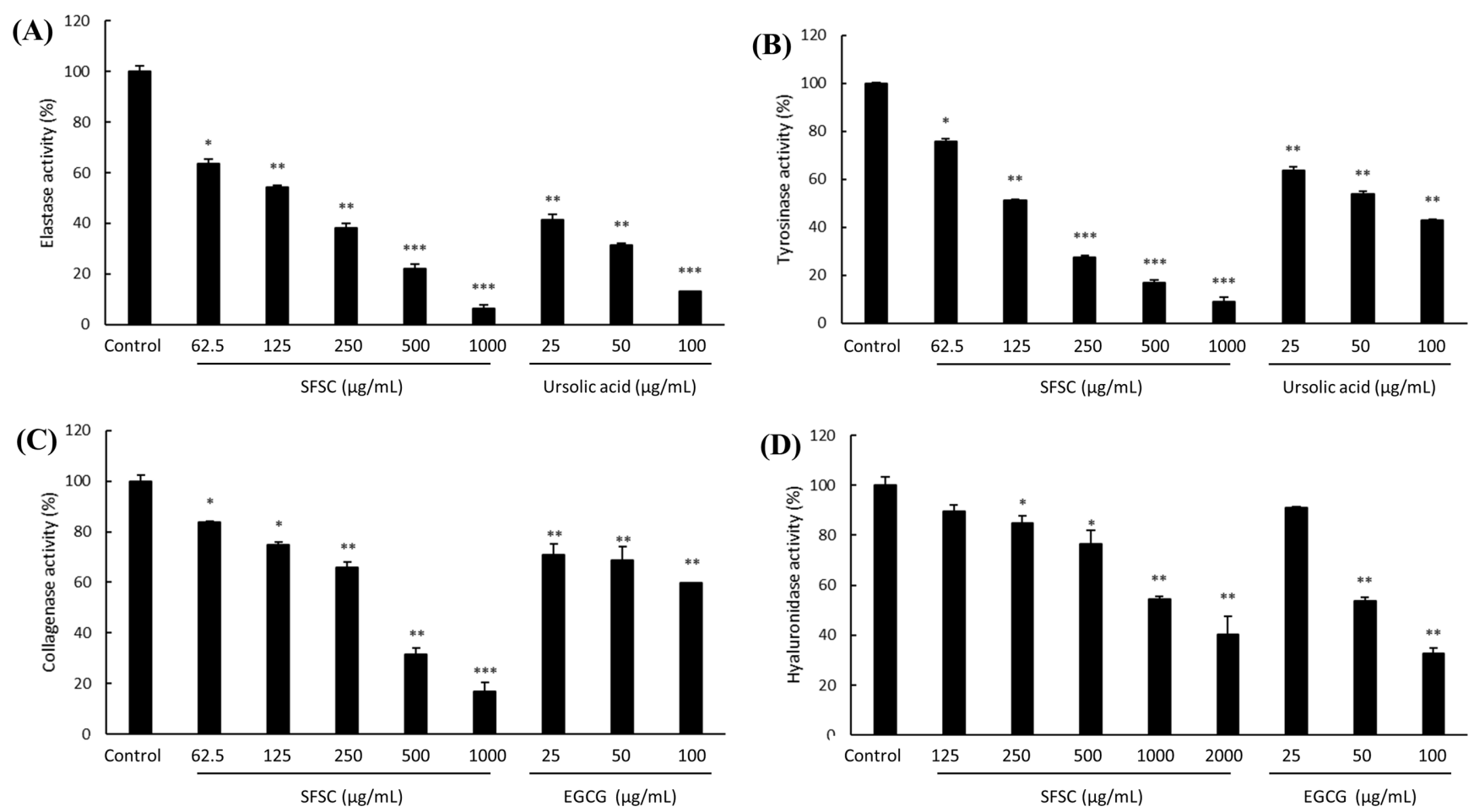

Fig. 2 Comparison of anti-aging skin activity between salted and fermented shrimps and positive control. (A) elastase activity. (B) tyrosinase activity. (C) collagenase activity. (D) hyaluronidase activity. All data are presented as the mean \pm SD of triplicate results. * represents $p<0.05$; **represents $p<0.01,{ }^{* * *}$ represents $p<0.001$ vs control)

scavenging effect at $6.25-100 \mu \mathrm{g} / \mathrm{mL}$ ranged from 15.32 to $56.99 \%$. BHA, a potent antioxidant compound, exhibited weak activity when compared with SFSC protein extract, similar to the value reported by [31]. These results support previous studies on antioxidant activities found in paste and raw materials obtained from shrimp [22]. They reported that DPPH radical scavenging activity of protein hydrolysates from $A$. indicus were $7.04 \mu \mathrm{M}$ Trolox/g. Furthermore, the activity obtained for SFSC was similar to that reported for silk sericin protein hydrolysates [32]. Scavenging potential is influenced by the amino acid composition. A high content of Lys and Asp has been found in many other antioxidant peptides [33]. This study appears to be the first reporting antioxidant peptides from fermented shrimp paste.

\section{Anti-aging inhibitory activities}

The inhibitory activity of SFSC on elastase and tyrosinase was compared to that of ursolic acid, which has been shown to be an effective agent for protecting skin cells against UVB. As shown in the Figure 2A, SFSC inhibited the activity of elastase in a dosedependent manner. SFSC concentrations of $62.5,125,250,500$, $1000 \mu \mathrm{g} / \mathrm{mL}$ inhibited elastase activity by $36.55 \pm 2.17,45.77 \pm$ $1.81,61.7 \pm 0.87,77.87 \pm 1.62$, and $93.52 \pm 1.91 \%$, respectively. The amount needed for $50 \%$ inhibition $\left(\mathrm{IC}_{50}\right)$ was $182.76 \pm 12.38 \mu \mathrm{g}$ / $\mathrm{mL}$. Ursolic acid, the positive control, demonstrated effective elastase inhibition. The inhibition of tyrosinase by SFSC is shown in Fig. 2B, and was also dose dependent. The highest inhibitory activity of SFSC on tyrosinase was $91.03 \pm 8.93 \%$ at $500 \mu \mathrm{g} / \mathrm{mL}$, compared to $57.21 \%$ at $100 \mu \mathrm{g} / \mathrm{mL}$ for ursolic acid. The inhibitory activity of SFSC on collagenase ranged from $24.32-91.03 \%$ at 62.5-1000 $\mu \mathrm{g} / \mathrm{mL}$, respectively, while epigallocatechin gallate inhibited collagenase by $36.23-57.21 \%$ at the concentrations tested. The $\mathrm{IC}_{50}$ of hyaluronidase inhibition for the SFSC sample was 1447.95 $\pm 28.92 \mu \mathrm{g} / \mathrm{mL}$.

Several studies have reported that fermentation increases the anti-aging activity of products [34,35]. Jang, Kim et al. [34] reported greater values for fermented Trapa japonica fruit than for protein extracted from fresh fruit. The results correspond to earlier findings of Fan, Zhuang et al. [36] and Chlapanidas, Faragò et al. [37] for protein extracts of marine organisms, both in vitro and in vivo. A study conducted by Abdillah, Wijayanti et al. [38] found that hydrolyzed collagen from sea cucumbers had an $\mathrm{IC}_{50}$ value of $125 \mu \mathrm{g} / \mathrm{mL}$.

Anti-aging activity may be due to the presence of various amino acids in protein extracts. Detailed knowledge of the molecular mechanisms underlying the effect of peptides on the aging of skin is limited. However, the increase in anti-aging activity found in protein hydrolysates might be explained by the fact that fermentation of protein is shown to be necessary for the release of active peptides from inactive protein, or the synthesis of new peptides by microorganisms [30]. The anti-photoaging effect of hexapeptide11, a peptide purified from Saccharomyces yeast fermentation, was evaluated both in vitro and in a clinical trial of 25 healthy 
Table 3 Sensory evaluation of salted and fermented shrimp products*

\begin{tabular}{lcc}
\hline \hline Free amino acid & SFS & SFSC \\
\hline Softness & $4.56 \pm 0.15$ & $4.61 \pm 0.32$ \\
Fibrousness & $3.12 \pm 0.11$ & $3.25 \pm 0.13$ \\
Sweetness & $1.66 \pm 0.52$ & $1.67 \pm 0.41$ \\
Bitterness & $1.30 \pm 0.25^{\mathrm{a}}$ & $2.20 \pm 0.21^{\mathrm{a}}$ \\
Sourness & $2.56 \pm 0.16$ & $2.25 \pm 0.11$ \\
Aromaintensity & $7.85 \pm 0.13^{\mathrm{a}}$ & $7.15 \pm 0.15^{\mathrm{b}}$ \\
Aftertaste & $6.56 \pm 0.07$ & $6.54 \pm 0.24$ \\
Accept ability & $9.41 \pm 0.27$ & $9.37 \pm 0.18$ \\
\hline
\end{tabular}

*Values presented are means of triplicates \pm SD

${ }^{\mathrm{a}, \mathrm{b}}$ The different letters in the same line represent that there are significant differences at the level of $p<0.05$

volunteers [39]. However, further study is required in the identification of bioactive peptides. Analysis of the amino acid composition of peptides responsible for the anti-wrinkle effect would provide insight into the evaluation or synthesis of new peptides that could ultimately replace conventional proteins in skin cosmetics.

\section{Sensory evaluation}

The results of sensory evaluation showed no difference in overall acceptability between conventional (SFS) and $S$. cibaria-fermented (SFSC) salted shrimps (Table 3). In comparison to SFS, SFSC scored higher for softness, fibrousness, and bitterness. Overall, $S$. cibaria fermentation did not change the sensorial characteristics of salted shrimp. Moreover, based on the results of the antioxidant and anti-wrinkle tests, this study demonstrates that salted shrimp subjected to fermentation by Salinivibrio cibaria is an important source of bioactive peptides that can potentially be used to develop nutricosmetic products.

In conclusion, this study suggests that the use of Salinivibrio cibaria BAO-01 as a starter culture in salted fermented shrimp may be a good strategy to enhance antioxidant and anti-wrinkle activities during fermentation. Concerning the sensory profile, the salted fermented shrimp s has an apparent positive impact. The outcomes of our study would be of practical interest to fermented shrimps, especially when the option for developing functional products through the selection of microorganism may be an option to produce fermented shrimp with potential new profiles. However, further researches on the safety properties and especially the impact of with long-term use of different shrimp varieties and concentration will be necessary.

Acknowledgment This study was carried out with the support of the Basic Science Research Program through the National Research Foundation of Korea (NRF) funded by the Ministry of Education (NRF-2017R1D1A3B 03027816).

Conflict of interest statement We declare that we have no conflicts of interest.

\section{References}

1. Alves A, Sousa E, Kijjoa A, Pinto M (2020) Marine-derived compounds with potential use as cosmeceuticals and nutricosmetics. Molecules 25: 2536

2. Bolduc JA, Collins JA, Loeser RF (2019) Reactive oxygen species, aging and articular cartilage homeostasis. Free Radic Biol Med 132: 7382

3. Zhou S, Cui Z, Urban JP (2004) Factors influencing the oxygen concentration gradient from the synovial surface of articular cartilage to the cartilage-bone interface: a modeling study. Arthritis Rheum 50: 3915-3924

4. Zaid AN, Al Ramahi R (2019) Depigmentation and anti-aging treatment by natural molecules. Curr Pharm Des 25: 2292-2312

5. Negahdaripour M, Owji H, Eslami M, Zamani M, Vakili B, Sabetian S, Nezafat N, Ghasemi Y (2019) Selected application of peptide molecules as pharmaceutical agents and in cosmeceuticals. Expert Opin Biol Ther 19: $1275-1287$

6. Dini I, Laneri S (2019) Nutricosmetics: A brief overview. Phytother Res 33: 3054-3063

7. Park YK, Lee JH, Mah J-H (2019) Occurrence and reduction of biogenic amines in kimchi and korean fermented seafood products. Foods 8: 547

8. Najafian L, Babji AS (2018) Fractionation and identification of novel antioxidant peptides from fermented fish (pekasam). Journal of Food Measurement and Characterization 12: 2174-2183

9. Kleekayai T, Harnedy PA, O'Keeffe MB, Poyarkov AA, CunhaNeves A, Suntornsuk W, FitzGerald RJ (2015) Extraction of antioxidant and ACE inhibitory peptides from Thai traditional fermented shrimp pastes. Food Chem 176: 441-447

10. Harnedy PA, FitzGerald RJ (2012) Bioactive peptides from marine processing waste and shellfish: A review. J. Funct. Foods 4: 6-24

11. Abuine R, Rathnayake AU, Byun H-G (2019) Biological activity of peptides purified from fish skin hydrolysates. Fisheries and aquatic sciences 22: 10

12. Kim D-U, Chung H-C, Choi J, Sakai Y, Lee B-Y (2018) Oral intake of low-molecular-weight collagen peptide improves hydration, elasticity, and wrinkling in human skin: A randomized, double-blind, placebocontrolled study. Nutrients 10: 826

13. Koo OK, Lee SJ, Chung KR, Jang DJ, Yang HJ, Kwon DY (2016) Korean traditional fermented fish products: jeotgal. J Ethn Foods 3: 107116

14. Song E-J, Lee E-S, Park S-L, Choi H-J, Roh SW, Nam Y-D (2018) Bacterial community analysis in three types of the fermented seafood, jeotgal, produced in South Korea. Biosci Biotechnol Biochem 82: 14441454

15. Le B, Yang SH (2018) Characterization of a chitinase from Salinivibrio sp. BAO1801 as an antifungal activity and a biocatalyst for producing chitobiose. J Basic Microbiol 58: 848-856

16. Le B, Chung G, Yang SH (2018) Chitinase-producing Salinivibrio bacteria isolated from salt-fermented shrimp with antimicrobial and safety assessments. J Appl Biol Chem 61: 233-238

17. AOAC (2010) Official methods of analysis of AOAC International. William Horwitz, AOAC International, Gaithersburg

18. Thuy LTM, Okazaki E, Osako K (2014) Isolation and characterization of acid-soluble collagen from the scales of marine fishes from Japan and Vietnam. Food Chem 149: 264-270

19. Yen G-C, Wu J-Y (1999) Antioxidant and radical scavenging properties of extracts from Ganoderma tsugae. Food Chem 65: 375-379

20. Cannell RJ, Kellam SJ, Owsianka AM, Walker JM (1988) Results of a large scale screen of microalgae for the production of protease inhibitors. Planta Med 54: 10-14

21. Schurink M, van Berkel WJ, Wichers HJ, Boeriu CG (2007) Novel peptides with tyrosinase inhibitory activity. Peptides 28: 485-495

22. Dhanabalan V, Xavier M, Kannuchamy N, Asha KK, Singh CB, Balange 
A (2017) Effect of processing conditions on degree of hydrolysis, ACE inhibition, and antioxidant activities of protein hydrolysate from Acetes indicus. Environmental Science and Pollution Research 24: 21222-21232

23. Synowiecki J, Al-Khateeb NAAQ (2000) The recovery of protein hydrolysate during enzymatic isolation of chitin from shrimp Crangon crangon processing discards. Food Chem 68: 147-152

24. Dhanabalan V, Xavier M, Murthy LN, Asha KK, Balange AK, Nayak BB (2020) Evaluation of physicochemical and functional properties of spraydried protein hydrolysate from nonpenaeid shrimp (Acetes indicus). J Sci Food Agric 100: 50-58

25. Ghorbel-Bellaaj O, Maalej H, Nasri M, Jellouli K (2018) Fermented shrimp waste hydrolysates: pomising source of functional molecules with antioxidant properties. Journal of culinary science $\&$ technology 16 : 357-377

26. Bueno-Solano C, López-Cervantes J, Campas-Baypoli O, LauterioGarcía R, Adan-Bante N, Sánchez-Machado D (2009) Chemical and biological characteristics of protein hydrolysates from fermented shrimp by-products. Food Chem 112: 671-675

27. Hoyle NT, Merrit JH (1994) Quality of fish protein hydrolysates from herring (Clupea harengus). J Food Sci 59: 76-79

28. Le Vo TD, Pham KT, Van Le VM, Lam HH, Huynh ON, Vo BC (2020) Evaluation of iron-binding capacity, amino acid composition, functional properties of Acetes japonicus proteolysate and identification of ironbinding peptides. Process Biochem

29. Masaki H (2010) Role of antioxidants in the skin: anti-aging effects. J Dermatol Sci 58: 85-90

30. Venkatesan J, Anil S, Kim S-K, Shim MS (2017) Marine fish proteins and peptides for cosmeceuticals: A review. Mar Drugs 15: 143

31. Ghorbel-Bellaaj O, Jellouli K, Maalej H (2017) Shrimp processing byproducts protein hydrolysates: Evaluation of antioxidant activity and application in biomass and proteases production. Biocatal Biotransform 35: $287-297$
32. Jena K, Pandey J, Kumari R, Sinha A, Gupta V, Singh G (2018) Tasar silk fiber waste sericin: new source for anti-elastase, anti-tyrosinase and anti-oxidant compounds. Int J Biol Macromol 114: 1102-1108

33. Barzideh Z, Latiff AA, Gan C-Y, Abedin M, Alias AK (2014) ACE inhibitory and antioxidant activities of collagen hydrolysates from the ribbon jellyfish (Chrysaora sp.). Food Technol Biotechnol 52: 495-504

34. Jang JD, Kim M, Nam G-H, Kim Y-M, Kang SM, Lee K-Y, Park Y-J (2020) Antiaging activity of peptide identified from fermented Trapa japonica fruit extract in human dermal fibroblasts. Evid Based Complement Alternat Med 2020

35. Park MH, Kim D-Y, Jang H-J, Jo YH, Jeong JT, Lee DY, Baek N-I, Ryu HW, Oh S-R (2019) Analysis of polyphenolic metabolites from Artemisia gmelinii Weber ex Stechm. and regional comparison in Korea. J Appl Biol Chem 62: 433-439

36. Fan J, Zhuang Y, Li B (2013) Effects of collagen and collagen hydrolysate from jellyfish umbrella on histological and immunity changes of mice photoaging. Nutrients 5: 223-233

37. Chlapanidas T, Faragò S, Lucconi G, Perteghella S, Galuzzi M, Mantelli M, Avanzini MA, Tosca MC, Marazzi M, Vigo D (2013) Sericins exhibit ROS-scavenging, anti-tyrosinase, anti-elastase, and in vitro immunomodulatory activities. Int J Biol Macromol 58: 47-56

38. Abdillah S, Wijayanti G, Setiawan M, Noor U, Nurilmala M (2017) In vitro anti-tyrosinase and anti-elastase activity of collagen from sea cucumber (Holothuria leucospilota). African Journal of Biotechnology 16: $771-776$

39. Emanuele E, Spencer JM, Braun M (2014) An experimental doubleblind irradiation study of a novel topical product (TPF 50) compared to other topical products with DNA repair enzymes, antioxidants, and growth factors with sunscreens: implications for preventing skin aging and cancer. Journal of drugs in dermatology: JDD 13: 309-314, Gorouhi F, Maibach H (2009) Role of topical peptides in preventing or treating aged skin. Int J Cosmetic Sci 31: 327-345 